\title{
PERSONAL PENSIONS AND THE FINANCIAL SERVICES AUTHORITY: NEW CHAPTER OR SAME OLD STORY?
}

\author{
Marina Milner and Keith Syrett, Norwich Law School, University of \\ East Anglia \\ INTRODUCTION
}

Despite origins embedded within Thatcherite anti-welfarist policies and ideologies of individual choice, the personal pension (PP) scheme appears to have become a permanent feature of the United Kingdom's pensions landscape. ${ }^{1}$ However, the revelation that large numbers of such schemes were 'mis-sold' to persons for whom they were not the most suitable option has prompted demands for "better regulation to restore confidence in the system". ${ }^{2}$ Against such a backdrop, the Labour Government has embarked upon a radical overhaul of the entire structure of financial services regulation, including that of PPs. This article seeks to assess the suitability of the new regulatory regime in the PP context, in view of the particular qualities that serve to distinguish this product sharply from others in the financial services marketplace.

\section{PENSIONS MIS-SELLING: A BRIEF BACKGROUND}

PPs are regulated as emanations of the financial services industry. As such, under the Financial Services Act 1986, they were subject to the powers of the Securities and Investments Board (SIB) and the relevant self-regulatory organisations (SROs). It is noteworthy that at no time was any single SRO responsible for the regulation of PPs per se; instead, tasks were divided along functional lines. When evidence of mis-selling began to emerge, the key SROs were Fimbra, which regulated Independent Financial Advisers (IFAs), and Lautro, responsible for regulating life offices. Between 1990 and 1992, Lautro and Fimbra began to receive information that suggested low levels of compliance with regulatory standards. In July 1992, the SROs therefore issued more particular guidance as to what was required, ${ }^{3}$ and the following year SIB commissioned a report by KPMG Peat Marwick to investigate compliance with these new guidelines.

The report revealed that those who had been in occupational pension (OP) schemes were being advised to transfer to PPs, even though these were less suitable because (for example) they did not receive employer contributions and did not guarantee a salary-related level of income on retirement. Similarly, those who could have joined an occupational scheme did not do

1 Current proposals for pensions reform envisage a growing role for private provision, including PPs: see DSS, A new contract for welfare: partnership in pensions (1998; Cm 4179): passim.

2 Ibid., Summary, para 34.

3 See now SIB, Pension Transfers and Opt-Outs - Further Safeguards for Future Business Trends (March 1994); Pension Transfers and Opt-Outs: Model Guidance (May 1994) etc. 
so, on advice, and instead bought PPs. The report referred to "widespread regulatory compliance failure" of making good the mistakes made has since been estimated variously at $£ 4$ billion to $£ 11$ billion. $^{5}$

The reasons for such large-scale breach have been analysed fully elsewhere. ${ }^{6}$ It is submitted here that pension provision is a unique activity and that the PP is unlike any other form of financial service. Regulation must identify and manage the particular risks that continue to arise: the failure of the previous regime to do so may have contributed to its failure. The prospects for success of the new regulator and our proposals for the future will be considered below. First, however, the uniqueness of pension provision and PPs as manifestations of such provision will be explored.

\section{THE DISTINCTIVE QUALITIES OF PERSONAL PENSIONS}

\section{Social risk and pension provision}

In many senses, pension schemes are merely savings schemes - a type of financial service. Contributing to them or providing them is therefore an unremarkable economic activity. As an analysis of pension provision, however, this approach is unsatisfactory because it does not take account of the distinctive factors at issue. Pension provision caters for the risk of reaching old age without income. Unlike other forms of social risk, where the degree of risk is more uncertain, most people are more likely than not to grow old. In addition, the social convention of retirement from the job market, which is now so well-established as to be a norm, means that most will have to deal with the issue of how to support themselves during retirement. Although some will be well placed to do this, the risk of a "penurious old age" risks. Because it is so universal, the costs of dealing with it are huge: in 1990 , the combined expenditure on public and private pension schemes in the United Kingdom was approximately $11 \%$ of GDP. ${ }^{8}$ Government literally cannot afford not to deal with this form of risk, but its current income is not sufficient to underwrite it.

There is also another factor. It is well documented that the population is ageing, so that dependency ratios are falling: in 1953, there were 4.6 people of working age for every pensioner, which compares with 3.4 today and an

4 KPMG Report (1993), p 16.

5 See Occupational Pensions (March 1998), p 3 and Treasury Select Committee, Ninth Report, The Mis-Selling of Personal Pensions HC 712-I (1997-8), p x. There are no figures available enabling an estimate to be made of the numbers of PPs mis-sold in Northern Ireland: see 299 HC Deb 160 (written answer, 29 July 1997). However, the FSA has indicated its awareness that a problem exists (communication with authors).

6 See generally KPMG Report, op cit n 4; Black and Nobles, "Personal Pensions Mis-selling: The Causes and Lessons of Regulatory Failure" (1998) 61 MLR 789 at 793; and for matters following the pensions review see Treasury Select Committee, ibid.

7 Baldwin, The Politics of Social Security (1980), p 12.

8 Barr and Whynes, Current Issues in the Economics of Welfare (1993), p 45. 
estimated 2.4 by $2040 .{ }^{9}$ It will therefore become increasingly unrealistic to rely on current earners to support all non-earners. ${ }^{10}$ Nevertheless, assuming that the current philosophy of welfare survives, those who grow old will still need support. Plans are needed to stave off what could be a major economic problem.

The breadth of the risk faced and its financial consequences are not, however, the only factors that make this a unique issue for social policy. When ideas about social justice gained enough weight to be translated into government policy at the turn of the century, two elements on which the claim of the elderly to state support rested emerged, which made their demands very difficult to resist. Previously, the elderly had been treated as a subset of the poor and therefore subject to the same rules with regard to poor relief as others. However, there was a growing recognition of the destitution suffered by many of the elderly through poverty. Coupled with this was the fact that, unlike many other forms of social need, old age was often accompanied by undoubted desert. ${ }^{11}$ Although some individuals may have wasted away their lives in 'feckless poverty' (as proponents of the Poor Laws may have put it), many more seemed to be suffering poverty despite having worked all their lives. Thus, those claiming relief in old age could point to two justifications: need and desert - which otherwise have often been set in opposition to each other. ${ }^{12}$ In this respect they were perhaps unique amongst those claiming social support.

Partly because the risks faced are so great and expensive, therefore, and partly because, politically, the twin elements of need and desert are still apparent and powerful ${ }^{13}$, old age, retirement generally is now a distinct

9 DSS, op cit n 1, ch.1, para 27. Approximately 10 million people currently receive state pensions; by 2030, the number will rise to about 14 million: see Pension Provision Group, We all need pensions - the prospects for pension provision (1998), Part 2.

10 See further Miles and Timmermann, "Risk sharing and transition costs in the reform of pension systems in Europe" (1999) 29 Economic Policy 253 at 257. Note, however, that several commentators have cast doubt on the negative impact of the so-called 'demographic timebomb': see Vincent, "Who's Afraid of an Ageing Population?" (1993) 16 Critical Social Policy 3 at 23; Hills, The Future of Welfare: A Guide to the Debate (1993), pp 12-13; Barr and Whynes op cit $\mathrm{n} 8, \mathrm{p}$ 50 et seq.

11 For contemporaneous accounts and acknowledgement of need, as well as attitudes towards 'desert', see eg Spender, The State and Pensions in Old Age (1892), ch.1; and generally Committee on Old-Age Pensions, Old Age Pensions: A Collection of Short Papers (1903).

12 See $e g$ Baldwin, op cit n 7, p 31 et seq; and generally Miller, Social Justice (1976). For the history of the development of old age relief, see $e g$ Brown, Social Security for Retirement (1990), pp 3-47; and for insurance as a model for welfare provision, see Ogus et al, The Law of Social Security (1995), p 25 et seq.

13 See eg Pinker, Social Work in an Enterprise Society (1990), p 131, drawing on data from public opinion surveys. He notes the wide support for state health, education and pensions provision as compared with the unemployed; and comments on the implication that the former are 'deserving' groups. It is also interesting that the keynote of the Government's reform for welfare as a whole is that "work is the surest route out of poverty": see DSS, New ambitions for our country: a new contract for welfare (1998; Cm 3805), Summary, para 10, and generally. 
socio-political issue, and it has become necessary for government to make some provision for pensions. The cost element involved has meant that the choice of funding method has been an issue since state provision began. ${ }^{14}$ One solution is to adopt the 'savings model' of provision, where an individual saves income generated whilst economically active, so as to provide assets on which he can live in retirement. In this way, income can be drawn to support the current retired population "without any impact on the [current] working population"15. Politically, one of the crucial implications of this is the focus it places on the individual and current earnings, and the consequent non-involvement of the state and society either in provision itself or, in principle, in any failure of the individual's arrangements. Although it may be accepted that a certain level of state welfare provision is unavoidable (most western industrialised states now provide it at some level), if the current workforce is not involved in the support of its predecessors, then responsibility falls on the individual in each workforce to be self-reliant in retirement. This approach assumes that the individual can earn enough during a working life to amass adequate savings for retirement and implies that self-reliance and the effectiveness of the individual to provide for himself are paramount.

This can be contrasted with the so-called 'solidarity model'. ${ }^{16}$ As its name suggests, this involves a measure of collective action and responsibility for the welfare of all, born out of a sense of community within society ${ }^{17}$, it may be described as the acquisition by the 'retiree 'of a claim to output by the next generation of workers. ${ }^{18}$ Thus, if individuals fall foul of risk, society has a responsibility to help bear the cost consequences. Typically, social risk has been met through some form of re-distributive insurance ${ }^{19}$. This functions by recognising that there are certain risk pools into which more than one person might fall. Given this, the adverse consequences of those risks manifesting themselves can be minimised if all those at risk contribute money to a common fund, from which a cash sum can be paid to those for whom the risk does materialise. Within the private sector, this means "reapportioning the costs of risk and mischance" 20 amongst those in the risk pool (rather than, for example, re-distributing wealth per se). When social insurance is in question, two extra steps are taken. First, those who are not so clearly within the risk pool may contribute to the costs of insuring all who do fall within it; second,

14 In 1908. See eg Brown, op cit n 12, p 3 et seq.

15 Davies, Better Pensions for All (1993), p 7; and see further Barr and Whynes, op cit $\mathrm{n} 8$, $\mathrm{p} 48$ et seq.

16 Davies, ibid.

17 An example of the adoption of this approach in state policy is contained in Social Insurance and Allied Services ('the Beveridge Report', 1942; Cmd. 6404), para 26. In dealing with the eradication of 'Want' which affected inter alios the elderly, Beveridge aimed neither to raise living standards, nor to reduce inequality, but to "enhance a sense of collective belonging within society": Langan, Welfare, Needs, Rights and Risks (1998), p 8.

18 Barr and Whynes, op cit $\mathrm{n} 8, \mathrm{p} 48$.

19 This satisfies the 'desert' element of the claim to social support. See generally de Vries, "From Insurance State to Welfare State, and Back Again?" (1995) 20 Geneva Papers on Risk and Insurance 439.

20 Baldwin, op cit n 7, p 1. 
the cost of contributing to the fund may be re-apportioned a second time, this time according to ability to pay.

What is at issue here is not the justice or otherwise of the wealth redistribution aspects of social insurance as opposed to its risk reapportionment. It is simply to identify the characteristics of the vehicle chosen to meet, and defray the consequences of, the particular social risk. The PP appears to be a manifestation of the 'savings model' alone ${ }^{21}$ : it is tied specifically to the individual and its effectiveness for retirement provision depends on how much that individual sets aside during a working life. Although the basic state pension would currently provide some back-up cover if the model fails (resulting in inadequate pension provision), this is not linked per se to the creation and development of the PP. Hence, within the product itself there is no element of 'solidarity': there is no element of risk-spreading. Additional factors relating to the PP itself are that even if the most appropriate product is sold, investments may still fail, or return otherwise undermined because, say, of unfavourable annuity rates at the point of retirement. ${ }^{22}$ Since there is no security of return, it is possible for a buyer to draw out less than was paid in, no matter how much that might be.

Once again, the point is not to make a value judgement about the choice of funding method, but rather to analyse the effectiveness of the 'savings model' as a means of achieving the given end: the provision of income upon retirement. The equation of pension provision with finance through the PP has placed it in an environment (financial services) where the social and individual goals of provision may not be met because the means of funding exposes the buyer to unrecognised or unregulated risks. As we have seen, there is no guarantee that the financial mechanism for providing the pension will do so (as there is, for example, in both occupational and state pension schemes $)^{23}$. Focusing solely on the capital markets means also that there is

21 John Denham MP described these second pensions as "solely dependent on each individual's ability to work and save": speech to Northern Pensions Conference, "A Third Way for Pensions Reform" (10 July 1998). See also Miles and Timmermann, op cit n 10 at 254, who observe that the PP is a "pure defined contribution scheme. . . with no redistribution between or within cohorts".

22 Annuities provide income for life in return for the investment of a lump sum. Legally, those retiring with PPs or OPs must buy an annuity by age 75 . But annuity yields have dropped dramatically in recent years, with the loss of approximately $£ 5000$ pa income for every $£ 100,000$ invested. Some insurance companies guaranteed annuity rates in the 1970s and 1980s, when it was difficult to imagine that yields would drop so much; the cost to them of meeting these obligations has been estimated at $£ 14$ billion (see The Independent 3 March 1999, The Financial Times 14 August 1999). Although some companies appear to be honouring these promises (see The Independent 9 April 1999), the Equitable Life mutual insurance company has recently resisted a legal challenge to its policy to honour its guaranteed rates over only a small proportion (or none) of the fund values it invested on behalf of its members (so disappointing the expectations of some of its members, though in order, it argued, to achieve parity between all classes of member). See Equitable Life Assurance Society v Hyman, The Times 12 October 1999; and press reports generally.

23 Davies argues that "half the time people [buying PPs] will end up with a pension that is less than they were led to expect", op cit n 15, p 28. 
no cover for failure of individual provision, and no recognition of either desert or need.

The nature of the risks accompanying the PP is examined in further detail below. For the present, however, the problem and its repercussions might be expressed as follows. Whilst the origins of the discourse about pension provision may have been in welfare, the admitted practical difficulties of resourcing this specific aspect of welfare have meant that the focus of the debate has long since shifted to means of funding. Given the mechanism chosen, the dominant discourse surrounding the PP has become that of finance/investment. ${ }^{24}$ The financial services market may generally be an effective means of raising funds: that is not in issue. But within that particular discursive community, certain matters are taken for granted that demand more cautious treatment when pension provision is the only aim of the venture in question. Risk is the prime example. Those 'investing' inevitably face risk; indeed, the argument can be made that finance is about risk. The finance/investment discourse therefore allows us to dismiss concerns about the PP and the risks it presents to buyers simply by pointing to the nature of the 'game' involved:

"It is not reasonable to be protected against all possibility of losing money, or of making mistakes. . . finance is necessarily about risk, and therefore to attempt to regulate to remove all risk from the consumer would be a policy of regulating away the very function of finance and financial contracts". ${ }^{25}$

On this analysis, the most that regulation can achieve is to prevent people being 'made fools of' in financial terms ${ }^{26}$.

This surely misses a step. Pension provision per se is not about risk (except in the sense of managing social risk) and certainly not in the same way that finance/investment is. Salary-related OP schemes are examples of how the risks of investment are managed so that they do not fall on the intended 'retiree'; hence such schemes have a maximum chance of achieving their goal. ${ }^{27}$ Indeed, trustees who invest funds for OP schemes are subject to strict trust law rules regarding attitude to and levels of risk that are acceptable. ${ }^{28}$ We assume here that the overriding objective is to achieve the distinct social policy aim of providing adequate income on retirement. Given this, the risks inherent in the PP and the financial markets should at least be overtly

24 The most notable example being the definition of the PP as an 'investment' in the Financial Services Act 1986, Sched. 1, para 10.

25 Llewellyn, "Regulation of Retail Investment Services" [1995:Spring] Economic Affairs 12 at 16; also FSA, Meeting our Responsibilities (1998), para 47: "no system of regulation can insulate even retail customers from the responsibility of taking their own decisions on their savings and investments".

26 Gower, Review of Investor Protection, Part I (1984; Cm 9125), para 1.16.

27 Other types of risk may, of course, arise $e g$ from fraudulent employers as in the Maxwell case.

28 See Re Whiteley (1886) 33 Ch D 347 (CA): "the duty of a trustee is. . to take such care as an ordinary prudent man would take if he were minded to make an investment for the benefit of other people whom he felt morally bound to provide", per Lindley LJ at 355. 
recognised and managed, through regulation. The nature of these risks will next be examined.

\section{An environment of risk}

The PP involves numerous forms of risk. The first encountered are those inherent in making any form of pension choice. The mis-selling saga highlights some of these: an individual considering pension provision may, if employed, have to consider whether to join an OP scheme rather than taking out a PP, or to opt out of one in favour of a PP. Many find this a confusing choice, ${ }^{29}$ while others may make it on non-financial grounds; ${ }^{30}$ but those in secure employment with access to a good OP scheme may be exposed to a higher risk of receiving less on retirement if they buy a PP because PPs generally do not attract employer contributions and do attract fees and commission. Even given a financially knowledgeable decision - and even if an employer makes contributions to a PP - factors such as investment performance, the structure of commission and fees charged, and annuity rates at the point of retirement may all combine to make the PP less successful than the OP. ${ }^{31}$

Quite apart from the risks inherent in choosing between OPs and PPs, as illustrated by mis-selling, there are investment risks inherent in any type of funded scheme. The conclusions of Miles and Timmermann illustrate this. They have examined the relative efficiency of funded and unfunded provision by governments across Europe and note that accepted wisdom appears to understate "significantly. . . the true volatility of the terminal value of portfolios". They find that the number of recessions that are experienced during the "active work and savings period" of a particular age cohort of the population cannot be evened out over time, despite the commonly held belief that the contrary is true, and conclude that "even in the long run, the risk of funded pensions in the stock market can be considerable". ${ }^{32}$ In the light of the findings that all funded schemes involve risk, those inherent in PPs may be viewed as particularly significant, given the absence of any possibility of risk-sharing in such vehicles. ${ }^{33}$ These are important points when considering the suitability of the PP for the social goal of pension provision.

Some types of risk have already been recognised and addressed by regulatory authorities in response to the mis-selling episode. ${ }^{34}$ However, other forms of risk remain as inevitable consequences of the PP's location within the markets and within the discourse of financial speculation. Here the risk is that investments can fail as well as succeed. Varying degrees of such risk exist: at one level, there is a situation approaching chaos, or maximum risk of financial loss. No distinction is made between the individual and the

29 See eg Pensions Law Reform Committee Report ('the Goode Report', 1993; Cm 2342), vol. II, Research Report 2 (generally).

30 Because, for example, of distrust of the employer: see Goode Report, ibid, at 135.

31 I.e. because the return from the PP may be less than the pre-defined income guaranteed by formula under a salary-related OP

32 Miles and Timmermann, op cit $\mathrm{n} 10$ at 266, 254, 270, respectively.

33 See above, $\mathrm{n} 21$ and accompanying text.

34 Above $n 3$. 
corporate investor: each is responsible for fact-finding and choice of investment or provider, and the investor who chooses well can make large profits. ${ }^{35}$ The opposite condition is one of complete security for the individual: he is guaranteed not to lose money and in some situations will be guaranteed a certain return. This will be important if he is relying on that return to live on, having no other means of support; however, profits are likely to be relatively small and investment return relatively slow.

These risks are confronted by a 'spectrum' of investors/consumers. ${ }^{36}$ The characteristics of each individual will include rational capacity, wealth (disposable cash or otherwise) and attitude to risk. The PP purchaser might, as part of any of these characteristics or in addition, also be affected by the level of need for income on retirement. These attributes can combine in several ways to produce a consumer who is 'vulnerable' to varying degrees, ranging from the investor with plenty of disposable cash and who is happy to take any kind of risk, however great, to an individual (such as our PP consumer) purchasing with the specific purpose of living on the funds raised because no other income will be available at that time.

Various factors will determine where any individual will sit within the 'risk environment', not all of which will necessarily foster the desired outcome: that is, to ensure that the retirement provision vehicle chosen is in fact likely to provide adequate income in retirement. One such factor relates to the nature of the market involved: wholesale, that is, investments commonly dealt in by professional investors; or retail, where consumers are involved. Focusing solely on the retail market, the nature and level of sophistication of the individual next becomes relevant. Black describes retail market consumers as, at one and the same time, "usually unsophisticated with a low level of understanding of the financial products they are buying", uninterested and unwilling to shop around or find out more; yet feeling capable of handling their own finances. ${ }^{37}$ As she says, "[t]his dissonant combination of confidence and lack of sophistication suggests that

35 See Pagnano, "Discussion" in Miles and Timmermann, op cit n 10 at 281: "as any student of capital markets knows - higher expected rates of return come at the cost of greater risk".

36 The new regulator has argued for a three-way classification of consumers, distinguishing between professional traders, "expert end-users" and the man in the street: see Joint Committee on Financial Services and Markets, First Report, Draft Financial Services and Markets Bill HC 328-I (1998-9), para 28. The Government, however prefers to view the range of consumers/investors as a spectrum, so allowing for more subtle gradations between the categories: see below, $\mathrm{n} 79$.

37 Black, Rules and Regulators (1997), p 143, citing OFT study (1992). Other research shows that those with PPs (and members of OP schemes) were more likely than those receiving the State Earnings Related Pension to have thought "a lot" or "some" about pension provision in general and that a high proportion (about one half of the sample) felt that they had "very" or "fairly good" understanding of their schemes. The same survey reveals low levels of understanding about pension choices in general and the specifics of PP design: see Williams and Field, Pension Choices, A Survey on personal pensions in comparison with other options, DSS Research Report 22 (1993), paras 1.4 and 1.7 respectively. On the latter see also the Goode Report, Research Reports 1 and 2, op cit $\mathrm{n} 29$. 
consumers are especially vulnerable on savings and investment issues". ${ }^{38}$ She also points out the dangers of combining this type of consumer with a complex and opaque product such as the PP and the risk inherent in the competitive market. ${ }^{39}$ Such difficulties are particularly acute for the poor, largely because of inequalities of status between users and providers, especially when one party has a "monopoly, or near monopoly, of expert knowledge". ${ }^{40}$ Nor is the provision of additional information necessarily helpful in redressing the balance, as consumers can simply be confused by it. $^{41}$

Thus the PP market faces general difficulties in terms of competition, which increase the risk factors faced by our consumer. In addition, there are issues that specifically relate to the PP product. As Pinker states, the "ultimate sanction of the buyer [of such services/products] . . is his ability to withdraw his custom altogether" ${ }^{42}$ It is, however, difficult for the buyer of a PP to do so. For some, the PP replaces state provision for a socially recognised need (and it was promoted for this purpose). ${ }^{43}$ In this situation, withdrawal is very difficult. Also, because of the nature of the PP mechanism, it is difficult for a consumer to know when it might be advantageous to withdraw. As Simpson argues, the future investment performance on which the buyer depends is something that can be estimated, but not known. In any event, withdrawing too early from the PP can be disastrous for an ends-oriented consumer: the commission due on some products is paid out of the early contributions made - say, over a period of two years. This means that no return will be made on the investment during that time. The ideal, therefore, may be for a PP contract to last for a long period, but this in turn means that the consumer does not gain experience of the product by frequent purchase. Nevertheless, the PP involves an ongoing financial commitment that may absorb a large

38 Black ibid, citing research commissioned by SIB and Lautro (1991).

39 Ogus et al make a similar, general comment, that the market model of welfare "assumes that individuals have the information available and the capacity to make rational, wise decisions concerning current and future welfare; unhappily, this is not always a realistic assumption" (emphasis added): op cit $\mathrm{n} 12$, pp 9-10.

40 Pinker, Social Theory and Social Policy (1979), p 143. He argues that the poor "lack the money to claim parity. . . Normatively and relationally they learn to define themselves as inferior persons, subordinate in terms of both money and knowledge". The Pension Provision Group has observed that lower income groups are more vulnerable to the risk element that is inherent in PPs, op cit n 9, p 83. Davies has also commented on the impracticality and ineffectiveness of the PP as a means of pension provision for those on a low income, op cit $\mathrm{n} 15$, pp 24-29. See further below, n 118.

41 The Consumers' Association has commented that existing disclosure of information on charges "had not. . . resulted in a fall or increased competition, as consumers were 'confused by this plethora of information'": see Treasury Select Committee, op cit $\mathrm{n} 5$, $\mathrm{p}$ ix.

42 Pinker, op cit $\mathrm{n}$ 40, $\mathrm{p} 144$.

43 This phenomenon has been described as 'coerced exchange'. This is the idea that "people may effectively be 'coerced' into buying goods or services for which they previously depended upon state provision", hence preventing a reduction in welfare rather than increasing it per se: see Dunleavy, "The Growth of Sectoral Cleavages and the Stabilization of State Expenditures" (1986) 4 Society and Space 129 at 143. 
proportion of the consumer's wealth, which has corresponding implications for any mistakes made. ${ }^{44}$

Whilst PPs therefore rely on the free market to provide an adequate source of pension provision, this ideal scenario is inherently skewed because the consumers will frequently not act appropriately for the market mechanism to work effectively. In terms of placing consumers within the 'risk environment', the factors identified in this section mean that the decisions they take are high-risk, because they will be less able to deal with the greater knowledge, power and sophistication of those selling a product which may often appear complex. Hence, they face a greater risk of losing money, and therefore of failing to secure adequate retirement income.

\section{Regulatory consequences: the management of risk}

Each of the risks identified above contributes to the danger that the PP product will 'fail' in its objective: the provision of retirement income. It is this objective, and the accompanying social and political consequences, that makes the PP distinct from other types of 'investment' in the financial markets.

We argue, therefore, that attention should concentrate on the central purpose of the PP, rather than the mechanism (financial services) by which it is funded. The goal is pension provision rather than investment, the point being "not to build up an assignable asset but rather to provide a means of fiscal security for the pensioner and his family". ${ }^{45}$ The technical design of the PP supports this objective: in order to obtain tax exemptions, providers must incorporate a contractual prohibition on assignment. ${ }^{46}$ It is designed for the sole purpose of security in retirement, and since the funds are not available until an agreed retirement age, individuals are unlikely to see it in any other light. Even if those who are better off buy PPs, their purpose will still be retirement income: a PP consumer who can 'afford to lose' the money contributed because he has other sources of income will still focus on the ultimate outcome of the investment, not on the investment activity itself. Its loss therefore signals the profound failure of the venture. This is especially so, the needier the individual concerned. The fact that, for example, NHS workers and miners were among the victims of mis-selling - a function of previous government policy that all levels of worker could purchase them demonstrates the special dangers arising when those who genuinely need the income from PPs buy them.

44 Simpson, Regulating Pensions: Too Many Rules, Too Little Competition? (1996), p 20. Again, the Treasury Select Committee comes to similar conclusions: op cit $\mathrm{n}$ 5 , p ix.

45 Thomas, "Bankruptcy in Occupational Pension Schemes and Personal Pension Schemes: A Dichotomy of Approach" [1998] Conveyancer 317 at 325. The National Consumer Council also appears to recognise this approach: "our view is that. . the people who are buying [are doing so] really not as an expert purchase but as a means to an end, to greater security in old age or whatever... those people need a different level of protection from the people who [invest etc] as a business": evidence to the Joint Committee, op cit n 36 (vol. II), para 141.

${ }^{46}$ See Income and Corporation Taxes Act 1988, s 634(6). 
These singular factors carry particular ramifications both for the objectives of regulation and the design of regulatory institutions. It has been argued that "the most powerful economic justification for public intervention is the correction of market failure". ${ }^{47}$ The goal of regulation here should be to reduce the prospect of such failure, by focusing closely upon controlling the risks to which consumers remain exposed as a result of the location of the product in the financial marketplace. This will maximise the chance that the PP will achieve its social policy aims. It is not enough simply to prevent the consumer from "being made a fool of". ${ }^{48}$ The latter objective may be appropriate for other financial products, but the individual, social and political consequences of failure of the PP are such that only very low levels of risk are acceptable. The regulator must accordingly attempt to position the PP purchaser in a low-risk environment, which will entail assuming a relatively unsophisticated customer with a low tolerance of risk and a riskaverse investment portfolio. ${ }^{49}$

The need for this form of regulation distinguishes the PP from other financial service products. ${ }^{50}$ Indeed, it can be argued that the use of PPs as an instrument of government policy, to meet a particular and pervasive social risk, gives rise to 'public interest' considerations more closely analogous to those that exist in utility products:

"if people are to have a reasonably good quality of life, gas and water services must be provided. I simply contend that some financial service products - such as those producing a decent retirement income - are also necessary in ensuring that people have a good quality of life". ${ }^{51}$

This is especially so given their continued role in supplementing state provision in future government plans for the welfare system. ${ }^{52}$ All of these factors point to the need for a regulator to adopt an approach which differentiates between the PP and other financial service products, recognising its unique characteristics and purpose and managing risks accordingly.

It has been argued that the regulatory institutions governed by the Financial Services Act 1986 "did not have a detailed awareness of the particular nature of PPs" and hence did not conceive the PP product as problematic. ${ }^{53}$ The necessary level of differentiation between products was not achieved, with the regulators monitoring "the whole of a firm's business across the spectrum of its regulated activities" 54 , rather than recognising the distinctive qualities and

47 Bishop et al, The Regulatory Challenge (1995), p 3.

48 See Gower, above $\mathrm{n} 26$.

49 See further Miles and Timmermann, op cit n 10 at 277, who argue for "some role for government to play in setting up guidelines for diversification and risk management service".

50 It is acknowledged that there are other financial products that aim at retirement provision; it is submitted that these should be subjected to the same risk analysis and regulatory regime suggested here for pensions.

51 Love, 334 HC Deb 97 (28 June 1999).

52 See below, $\mathrm{n} 118$. Also note that it is difficult for IFAs to advise moving out of PPs, for example because of the controls on 'churning': see SIB core rule 26(1) hence advice is likely to be to retain the product once it is purchased.

53 Black and Nobles, op cit $\mathrm{n} 6$ at 813.

54 Ibid. 
difficulties associated with PPs. This can be seen as a consequence of the institutional structure of regulation, which entailed the PP product being overseen by two SROs, both responsible for a variety of other financial service products in which higher levels of risk were acceptable. ${ }^{55} \mathrm{~A}$ further difficulty was the absence of a statutory principle of consumer protection in the 1986 $\mathrm{Act}^{56}$, which might have shifted the regulatory focus away from the investor towards the more vulnerable consumer, prepared to tolerate only low levels of risk.

It may be over simplistic to ascribe the mis-selling of personal pensions solely to the inappropriate nature of the regulatory style and structure emerging from the $1986 \mathrm{Act}^{57}$; nor do we take issue with government regulation per se. It is our contention, however, that the previous regime was seriously flawed in its failure to account for and react to the distinctive characteristics and specific risks inherent in the PP product. The question which must now be addressed is: will the new regulator, the Financial Services Authority (FSA), be any better placed to do so?

\section{THE FSA: THE RIGHT REGULATORY TOOL FOR THE JOB?}

\section{Creating the FSA}

The radical overhaul of the structure of financial services regulation which was announced by the new Chancellor in May 1997 took commentators by surprise. ${ }^{58}$ Arguing that "the regulatory structure introduced by the Financial Services Act 1986 is not delivering the standard of supervision and investor protection that the industry and the public have a right to expect" and criticising the "inefficient" division of responsibility between SIB and the other regulatory bodies, he announced that work was to begin on legislation to simplify the regulatory system..$^{59}$ The new regulator was to take the form of a statutory 'super-SIB', with responsibility for all aspects of banking and financial services regulation, although the Bank of England would retain responsibility for overall systemic regulation.

The single regulator, christened the Financial Services Authority, came into being on 28 October 1997 . The regulatory functions and powers previously exercised by the institutions governed by the 1986 Act will be vested in the FSA by means of a Financial Services and Markets Bill, likely to receive

55 Although the replacement of Fimbra and Lautro by one regulator, the Personal Investment Authority (PIA), in 1994 may have reduced duplication of tasks, the responsibilities of this agency continued to extend well beyond the PP context.

56 An omission particularly criticised by the National Consumer Council: see Financial Services and Markets Bill: Response to the Treasury's consultation on the draft Bill (1999), p 3.

57 See Davies, in evidence to Treasury Select Committee, Third Report, Financial Services Regulation HC 73-II (1998-9), para 216; and for a discussion of other contributory factors, see Black and Nobles, op cit n 6. It is important to note, however, the use of the mis-selling episode as a key argument for regulatory reform: see below, n 66 and accompanying text.

58 See eg "Labour turns to the City", The Economist (24 May 1997), p 15.

59 Brown, 294 HC Deb 509 (20 May 1997). 
Royal Assent in spring 2000. ${ }^{60}$ The legislation, and hence the regulatory regime, extends to Northern Ireland. ${ }^{61}$ The Authority operates in effect as a statutory arm's-length government agency with a governing Board appointed by the Treasury and accountable to Parliament; but in legal form it is a private company limited by guarantee, funded by levies on the financial services industry.

\section{The FSA and PPs: grounds for optimism}

An evaluation of the likely effectiveness of the new regulator in addressing the particular challenges presented by the PP product necessitates discussion of the reasons for its creation, its statutory objectives and the approach that it proposes to adopt in the exercise of its powers.

The Government identified two broad rationales for overhauling the regulatory regime, and for the model adopted. Treasury ministers argued that a single regulator would reduce duplication of effort (and hence compliance costs) and better reflect the structure of a modern, global and integrated financial services industry, in which distinctions between types of institution are increasingly blurred. ${ }^{62}$ Regulatory reform was therefore linked to prosperity and international competitiveness, as well as Labour's broader 'modernising' agenda. ${ }^{63}$ This justification, which might be described as emanating from structural change, thus related to wider developments in financial markets, rather than the PP 'problem' in particular. ${ }^{64}$

The second - and here more instructive - rationale was systemic confidence, based on a critique of the previous 'self-regulatory' regime. In support of the argument that self-regulation, while attempting to protect the interests of the financial services industry as well as those of the public, ultimately did neither, ${ }^{65}$ the Government marshalled as evidence incidents in which past regulatory performance appeared defective, chief among which was misselling:

60 HC Bill 121 (1998-9). It received its First Reading on 17 June 1999, by which time it had already been subject to extensive consultation and pre-legislative scrutiny: see Joint Committee, op cit $\mathrm{n} 36$, para 2. This process may in part have been designed to answer criticism that the effective creation of the FSA before the passage of its enabling legislation precluded adequate debate on the reforms: see Taylor, "Unanswered questions for the UK's new leviathan" (1997) 2(4) The Financial Regulator 42.

61 Clause 364. Excluded are provisions regarding open-ended investment companies, which are not relevant here.

62 See Brown, above n 59 at 510; Milburn, 334 HC Deb 37 (28 June 1999).

63 See especially Byers, speech to Corporation of London Finance Committee, Treasury Press Release 201/98 (26 November 1998).

64 Although implications exist for the speed and effectiveness of the regulatory response to issues such as mis-selling: see below, $\mathrm{n} 86$ and accompanying text. For further discussion, see Goodhart et al, Financial Regulation: why, how and where now? (1998), ch.8.

65 See O'Brien, "Regulatory change - revolution or reform?" (1996) 1(3) The Financial Regulator 17 at 18; Darling, speech to FSA European Conference, Treasury Press Release 201/98 (26 November 1998), para 30. 
"the scale of personal pensions mis-selling has made it absolutely critical that, for consumer confidence, there now has to be a more transparent, a much simpler system of regulation that is not self-regulation. Personal pensions misselling brought the whole ethos of self-regulation into disrepute". ${ }^{66}$

Accordingly, the professed goal of reform was to "increase public confidence in the regulatory regime" 67 and in the markets, by restructuring regulation so that it was perceived as more independent, transparent, accessible and robust in its responses to market failure. ${ }^{68}$ These qualities provided a link with the structural objective of simplification and pointed towards the creation of a statutory single regulator which could react more efficiently and effectively to crises such as pensions mis-selling.

The issue of public and consumer confidence lies, therefore, at the very heart of the FSA's raison d'être, and the mis-selling episode offers both a specific justification for dismantling the previous regulatory regime and an illustration of the sort of incident that must be avoided in future. Consequently, it might be expected that the FSA will focus on measures to enhance public confidence and to protect the consumer, with those arising in the pension context particularly highlighted.

There is strong support for the view that that "the FSA's primary remit will be to protect the consumer". ${ }^{69}$ The Financial Services and Markets Bill specifies the promotion of "public understanding of the financial system"70 and the "appropriate degree of protection of consumers" of the new regulator, ${ }^{72}$ while the FSA has described consumer protection as "at the heart of the work of the Authority" task"74. This might lead one to predict that the FSA will pay close attention to the effective management and reduction of the risks faced by consumers within the financial marketplace - for example, by redressing asymmetries of information.

66 Liddell, in evidence to Treasury Select Committee, op cit n 5 (vol. II), para 21; see also Brown, letter to Chairman of SIB, Treasury Press Release 49/97 (20 May 1997): "The government is committed to reform... to reduce the chance of events such as the mis-selling of personal pensions happening again"; also Milburn, above n 62 at 38; and for comment, Taylor, op cit n 60 at 43, 45.

67 Brown, above n 59.

68 See Foreword (Brown), Financial Services and Markets Bill: A Consultation Document (Part 1) (1998).

69 Taylor, op cit $\mathrm{n} 60$ at 43. Such a focus is perhaps unsurprising, given the shift in regulatory attention towards consumer and public interest issues in recent years, reflected elsewhere by the priority given to consumer interests in proposals for the reform of utilities regulation: see DTI, A Fair Deal for Consumers (1998; Cm 3898).

70 Clause 4

71 Clause 5(1).

72 Additionally, clause 9 of the Bill requires the establishment and maintenance of a panel "to represent the interests of consumers".

73 FSA, op cit $\mathrm{n} 25$, para 43

74 Davies, speech at FSA Launch Conference (28 October 1997). 
But by itself, a commitment to 'protecting the consumer' - although preferable on our analysis to an approach that simply seeks to 'prevent him from being made a fool of' - may not be sufficient. We have argued above that the nature and purpose of the PP product and the consequent need for the reduction of risk, distinguish it from other transactions within the financial services market. It is important, therefore, that the FSA should take a differentiated approach to consumer protection, allowing it to intervene to a degree which would be inappropriate with other products in order to minimise the risks that might prevent the PP from fulfilling its objective. To what extent can the Authority be expected to adopt the necessary varied and flexible approach to its regulatory tasks?

A definitive response cannot be given at this stage, but a number of early indications exist. The Bill requires the FSA to have regard to the principle of caveat emptor ${ }^{75}$, seen as necessary to avoid the risk of "moral hazard"76; but in considering the degree of consumer protection which is appropriate, it will attempt "to ensure that they [consumers] are not exposed to risks that they should not reasonably be expected to assume". ${ }^{77}$ This is reflected in provisions requiring the Authority to have regard to differing degrees of "risk involved in different kinds of investment or other transaction" and of "experience and expertise which different consumers may have in relation to different kinds of regulated activity", together with consumer needs for advice and accurate information. ${ }^{78}$ Here, therefore, is a statutory manifestation of the view that the variety of products and consumers demands "an appropriate level of consumer protection that will be greater in some cases than others" $" 79$, leaving it open to the FSA to apply differing levels of regulatory protection when undertaking its statutory functions. Thus, for example, the marketing and sale of life assurance could be regulated in a different fashion to that of PPs.

The FSA has already indicated that it is "committed to a flexible and differentiated approach", ${ }^{80}$ and has shown apparent awareness of the particular importance of such an approach in the PP context:

75 Clause 5 (2) (d).

76 Ie not requiring consumers to accept responsibility for actions would "give them no incentive to take appropriate decisions": Treasury, Financial Services and Markets Bill - Progress Report (1999), para 4.11.

77 FSA, Financial Services Authority: an outline (1997), para 2.

78 Clauses 5 (2) (a), (b) and (c).

79 Treasury, op cit $\mathrm{n}$ 76. Indeed, it is significant that the Government rejected calls from bodies such as the National Consumer Council (op cit n 56, p 3) to distinguish between 'retail' and 'wholesale' sectors, viewing this as "too blunt an instrument" (Treasury, ibid, para 4.8), which failed to take account of "a spectrum of types of customer within these broad categories": Financial Services and Markets Bill - Government Response to the Joint Committee's First Report (1999), para 2. See above, n 36 and accompanying text.

80 FSA, Designing the FSA Handbook of Rules and Guidance (1998), p 6; also Differentiated Regulatory Approaches - Future Regulation of Inter-professional Business (1998), pp 5,7. Note also its proposals to utilise 'risk-based' supervision, focusing on the nature of the activity, the extent of risk within firms and markets, the quality of management controls and the sophistication of the consumers involved: op cit $\mathrm{n} 77$, para 3 . 
"the personal pension is at one extreme of the spectrum of financial products. There are other savings and investments, such as simple deposit accounts which are much easier to understand. ... So it is clear that the nature of any regulation of the retail market should vary considerably across products, and in some cases very little regulation is needed". ${ }^{81}$

This would suggest, therefore, that we can expect the new regulator to exercise its statutory powers and duties in an adaptable manner, varying its style and level of regulation to respond adequately to the differing levels of risk existing within the financial services sector, and providing a greater level of protection in cases where - as with PPs - only very low levels of risk are acceptable. For the reasons previously advanced, such an outcome would be welcome.

\section{The FSA and PPs: potential pitfalls}

This outcome is, however, far from guaranteed. Despite the statutory provisions and early regulatory assurances, concerns have been voiced that the "FSA will fail to differentiate adequately. . . in the way that it approaches supervision and regulation", especially given the broad definition of 'consumer' contained in the Bill. ${ }^{82}$ If this proves to be so, there is a danger that the particular characteristics and problems associated with the PP product and consumer may once again be left unrecognised. We turn, therefore, to examine the factors lending credence to this gloomier prognosis.

The 'structural change' rationale presented the new regulatory regime as more efficient and a better reflection of developments in the financial services industry. ${ }^{83}$ Here, in arguing that "creating a single regulator with a single authorisation process, a single compensation scheme, a single ombudsman, and a single appeals tribunal, [will] reduce the amount of regulation while at the same time providing for greater accountability", ${ }^{84}$ the Government offered an integrative justification for regulatory reform. This was further evident in the emphasis placed upon the need to avoid the regulatory "turf wars" 85 that supposedly characterised the previous regime. A single regulator was regarded as being in a position to respond more effectively and speedily to incidents such as mis-selling:

"There can be little doubt that the regulatory response to previous mis-selling would have been more coherent, and more rapid, had it been managed in a single centre rather than being the responsibility of a number of separate organisations. Individuals in the regulatory network tried very hard to achieve coherence and co-operate with each other; the framework within which they were operating did not reward those efforts. The establishment of

81 Davies, Henry Thornton Lecture, FSA Press Release 87/98 (4 November 1998).

82 Joint Committee, op cit n 36, para 29. See further below, n 94.

83 Above, n 62 and accompanying text.

${ }^{84}$ Byers, above $\mathrm{n} 63$.

85 See Alexander, "A view from the market" (1997) 2(3) The Financial Regulator 28 at 28-9. 
the FSA as the single statutory regulator is putting an end to this regulatory fragmentation". 86

Pressure for an integrated form of regulation, reflected in the rhetoric of the "one-stop shop", ${ }^{87}$ has therefore been imprinted strongly within the FSA's collective genes from birth, and represents a strong countervailing trend to the differentiated approach discussed above.

Moreover, it is likely that as it grows into maturity, the Authority will demonstrate ever more powerful integrative tendencies. Organisational theory teaches that, in order to contain fragmentation, successful large organisations need to adopt integrative managerial devices to co-ordinate the range of tasks. ${ }^{88}$ When this factor is viewed alongside the Authority's deployment of a 'lead supervisor' approach to the regulation of financial conglomerates, ${ }^{89}$ and the impetus provided by regulated firms preferring a 'level playing field' to a differentiated style which might confer a regulatory advantage on their rivals,${ }^{90}$ it would appear that there is a strong possibility of the development of a monolithic organisational 'culture' or 'ethos' within the FSA:

"Large organisations tend to develop a corporate approach; indeed they usually take pride in doing so. A real danger is that the FSA may try to deal in much the same way with very different market sectors, and with different customers with different requirements". ${ }^{91}$

There are reasons to believe, therefore, that FSA regulation may not differentiate to the extent presently asserted, and that a more homogeneous approach may steadily evolve. The issue here is the nature of any 'culture' that emerges and its likely effect upon the regulator's handling of the PP product. On one level, it might be argued that an undifferentiated regulatory approach need not in itself be unduly troubling, provided it is one that remains oriented towards protecting consumers from risks faced in the financial markets. ${ }^{92}$ Given the prominence accorded to consumer protection

86 FSA, memorandum of evidence to Treasury Select Committee, op cit $\mathrm{n}$ 66, para 25; see also Davies, op cit n 57, para 219. The FSA has taken steps towards such a co-ordinated response by establishing, with PIA, a single integrated pensions review division: see FSA Press Release 07/97 (9 December 1997).

87 See Davies, in evidence to Treasury Select Committee, ibid, para 195; Milburn, above $\mathrm{n} 62$ at 35 .

88 See Handy, Understanding Organizations (4th ed., 1993), pp 203-9.

89 This entails an individual or team co-ordinating the activities of other FSA employees working within the agency's different divisions, and taking responsibility for the consolidation of the supervisory relationship between such a firm and the Authority: see FSA, op cit $\mathrm{n} 25$, para 35.

90 See Alexander, op cit $\mathrm{n} 85$ at 29: "we [NatWest Group] obviously want the FSA to develop a common culture and style so as to be consistent in its approach".

91 Lloyd, 334 HC Deb 80 (28 June 1999). The FSA has also emphasised the "benefits of a single regulatory culture": see The Financial Services Authority: Information Guide (1999), p 7.

92 The discourse of 'consumer' - as distinct from investor - which underpins the Bill would seem to focus regulatory attention on market risks faced by individuals: see Davies, above $\mathrm{n} 74$. 
issues in the creation of the FSA, this would indeed seem the most likely short-term outcome.

However, as argued above, a 'consumer orientation' is not enough in itself: if the particular risks inherent in the PP are to be effectively managed so that its social policy objective is realised, it is important that the regulator continues to differentiate between the PP purchaser and other types of consumer: in short, that it recognises the existence of a 'spectrum'. ${ }^{93}$ The integrative pressures previously outlined, coupled with the absence of a statutory distinction between types of 'consumer', create anxiety that the FSA may move towards a uniform approach to its consumer protection responsibilities across markets and products. ${ }^{94}$ In view of the retention of the caveat emptor principle, any such approach is most likely to be slanted towards an individual who is prepared to accept moderate levels of risk and responsibility, rather than the PP purchaser located in a 'low-risk environment': in other words, that "we will finish up with a regime fixed in the middle". 95

Furthermore, concern has been expressed that, over a longer period, there is a danger of 'regulatory capture' by the financial services industry. ${ }^{96}$ This is especially so given the difficulty of organising effective representation of consumers due to the disparate nature of their interests (and the benefits gained) and the lack of resources comparable to those of producers. ${ }^{97}$ The Authority may consequently develop an industry-oriented ethos, shifting its activity away from areas - such as PPs - where consumer protection issues are paramount, as well as exhibiting greater tolerance toward practices that create risks for consumers. Such an outcome may be all the more likely once the mis-selling episode has faded from media and political memories.

\section{The FSA and PPs: conclusion}

It is apparent from this discussion that it is, at present, impossible to be certain of the manner in which the FSA will approach its tasks. Initial indications point toward a differentiated style, ${ }^{98}$ allowing room for cautious optimism that there will be proper regulatory recognition of the distinctive

93 See above, n 79.

94 See Treasury, op cit n 76, para 4.8; National Consumer Council, op cit, n 56, Hall (National Consumer Council) in evidence to Joint Committee, op cit n 45, para 141.

95 Cable, HC Standing Committee A (15 July 1999).

96 See Consumers' Association, memorandum of evidence to Treasury Select Committee, op cit n 66, para 4: "It is by no means certain that the FSA will deliver an effective regulatory regime according to consumer principles. There is a real fear that the consumer interest will be marginalised by the industry lobby in such a huge organisation"; National Consumer Council, op cit n 56, pp 10-11: "over time, the financial services industry. . . may gain excessive influence over the Authority". Producer dominance has been viewed as a key feature of "selfregulation': see Alcock, "The New Financial Services Authority and Consumer Protection" (1998) 2 Company Financial and Insolvency Law Review 88 at 91-2.

97 See especially Olson, The Logic of Collective Action (1965), pp 165-6, endorsed in the context of the Bill by McKechnie (Consumers' Association), in evidence to Treasury Select Committee, op cit $\mathrm{n}$ 57, para 11.

98 See above, $\mathrm{n} 80$ and accompanying text. 
problems and characteristics of the PP. However, a powerful counter-trend towards integration is also evident from the FSA's origins, which may well grow stronger as the Authority evolves. If this tendency proves dominant, regulation of the PP product may once again become subsumed within wider financial service matters, with the likely consequence that the specialised risk management needed to achieve its distinctive policy goal is neglected.

That the FSA is conscious of these issues is apparent from its identification of the importance of "be[ing] alert to the need to strike a balance between the drive for integration and the maintenance of flexibility and appropriate differentiation". ${ }^{99}$ Nonetheless, given the concerns expressed here, it seems appropriate to put forward possible alternatives to the new regulatory regime, which might be better suited to the particular challenges offered by the PP.

\section{TOWARDS A NEW REGULATORY STRUCTURE?}

There are clear arguments for the retention of an arm's-length, statutory agency, whose perceived distance from industry interests is likely to be a key factor in reinstating public confidence in the personal pensions market. ${ }^{100}$ However, as previously discussed, "there are greater pressures towards undue uniformity within a single regulator - where every difference needs justification - than in specialist regulators which are clearly freer to develop their own distinctive approaches". ${ }^{101}$ Given the importance of differentiating PPs from other financial products, we therefore believe that the model should be such as to allow for greater regulatory specialisation.

Comparison may be drawn with the utilities sector, where bodies such as OFTEL and OFWAT regulate within a statutory framework set up for each individual industry. The objectives of a 'watchdog' in the competitive market for PPs might appear to be somewhat different from those of the utility regulators, whose major goals have been to stimulate competition and prevent abuse of monopoly power by the former nationalised companies; but there are indications that the 'utility watchdog' analogy has gained some ground. ${ }^{102}$ However, an even closer parallel exists within the pensions sector itself where the Occupational Pensions Regulatory Authority (OPRA) focuses solely on employer-run schemes, under the provisions of the Pensions Act 1995. An argument might be made for extending OPRA's regulatory responsibilities to PPs: this would detach the regulation of the "very particular business" 103 of pension selling from that of other financial products, while simultaneously emphasising the comparable social policy goals of the differing pension vehicles. However, care would need to be exercised as the industrial relations and trust-based form of the OP raises quite distinct legal and other problems from the PP, which centres on arms-

99 FSA, op cit $\mathrm{n} 25$, para 67.

100 See Hedges, Pensions and Retirement Planning, DSS Research Report 83 (1998).

101 Lomnicka, "Reforming UK Financial Services Regulation: The creation of a Single Regulator" [1999] JBL 480 at 489.

102 See Love, above n 51 and accompanying text; also the Treasury Select Committee's suggestion that promotion of competition might become a statutory objective of the FSA: op cit n 57 (vol. I), para 23, subsequently rejected by the Government: Treasury, op cit n 76, para 4.16.

103 Black and Nobles, op cit n 6 at 791. 
length contract - hence different skills and regulatory approaches may well be needed. ${ }^{104}$

The application of some form of sector-specific regulatory model to the PP situation would have a number of advantages. Most significantly, it would facilitate the development of a level of specialised agency expertise. This is perceived as being a key strength of the utility regulators, ${ }^{105}$ whose importance in the PP context has been emphasised by Black and Nobles. They claim that a feature of mis-selling was "regulatory blindness. . . No-one looked at pensions as posing particular problems because no-one knew or thought to look", and conclude that "the regulator needs to have specialist knowledge of individual product and business areas". ${ }^{106}$ The 'technical' complexity of the PP product, especially as regards issues such as the tax regime, buying out, obtaining transfer values, the fee and commission structures combined with perhaps unfamiliar investment media and the inevitably long-term and retirement-focused nature of the PP - in addition to the distinctive social policy issues discussed above - presents a particularly strong case for specialisation here.

Such expertise may, of course, be attainable within the much larger structure of the FSA, but it is submitted that a smaller, focused agency would be better placed to identify the particular risks associated with PPs, to devise an appropriate response to instances of market failure and to offer an environment in which the special knowledge and skills needed to regulate this product can be developed. As argued in parliamentary debate, "the problem with one-stop shopping is that the shop assistants may not know well the needs of their different types of customer or the characteristics of their different suppliers". ${ }^{107}$

Furthermore (and contrary to the argument for regulatory simplification advanced above), ${ }^{108}$ it may also be that a specialist agency can achieve a swifter and more flexible response to problems in the pensions arena than a larger, more bureaucratic organisation. ${ }^{109}$ And, while regulatory capture remains a theoretical possibility for such a body, just as with the FSA, the experiences of the utility regulators and OPRA to date suggest that such an outcome is unlikely. ${ }^{110}$

Two objections to such a reform of the structure of regulation may be raised, and met. Firstly, it would represent a return to a more complex regime, with

104 Black and Nobles, ibid at 793, identify the failure to compare the benefits of OPs with those of PPs as an illustration of mis-selling, but also stress the extent of the differences and the consequent need to develop specialised knowledge: at 790 , 794-5, 817-8. It is notable that the Government has decided against absorbing OPRA within the FSA and thus subjecting the two pension vehicles to the same regulatory regime: see Joint Committee, op cit n 36, Appendix 1.

105 See Harlow and Rawlings, Law and Administration (2nd ed., 1997), p 310.

106 Black and Nobles, op cit $\mathrm{n} 6$ at 789-90.

107 Lloyd, above $\mathrm{n} 91$ at 79-80.

108 See above, n 86 and accompanying text.

109 For discussion of the view that the FSA's size is likely to result in unresponsiveness, see Davies, above n 74.

110 On the utility regulators, see Corry et al, Regulating Our Utilities (1994), pp 745. 
firms regulated by different agencies according to whether they are conducting pension or other types of financial business. This apparently offends against one of the Government's main rationales for structural change, reflected in the "one-stop shop" rhetoric. There are already, however, some significant exclusions from the FSA's regulatory scope. ${ }^{111}$ Moreover, it is interesting that recent proposals for the creation of 'stakeholder' pension schemes envisage regulation by two bodies: the FSA will regulate the marketing of schemes and provision of advice, while OPRA will oversee the operation of schemes. ${ }^{112}$ These factors suggest that the Government does not regard the 'single regulator' solution as an article of faith, and that it is prepared to contemplate variations on this structure where appropriate. ${ }^{113}$ Our view is that PPs are sufficiently distinctive to require just such a departure from the regulatory norm.

Secondly, one might query the practicability of setting up such a specialised agency, given that the FSA is already discharging its regulatory functions within the PP market. Adjusting the regulatory structure once more would delay the legislative process and cause considerable disruption for firms, consumers and regulatory staff alike. ${ }^{114}$ However, acceptance of this argument may result in "the organisational tail. . . wagging the legislative dog": ${ }^{115}$ it is surely preferable to address possible deficiencies at a relatively early stage rather than to revisit them in subsequent legislation. In any event, it would be possible to allow for creation of a specialised regulator without significantly delaying the passage of the Financial Services and Markets Bill by the simple expedient of inserting an amendment allowing the FSA to delegate its powers and duties to another body which met prescribed statutory standards. ${ }^{116}$ This would allow for dispassionate, carefullyconsidered theorising focusing upon the type of regulator which best suits pension provision in general and the PP market and the regulatory difficulties it presents in particular. ${ }^{117}$

111 Notably mortgages, which have not previously been subject to the statutory financial services regime: see Joint Committee, op cit n 36, paras 63-89. This exclusion is presently under review: see Treasury, Regulation of Mortgages: A Discussion Document (1999).

112 See DSS, Stakeholder Pensions: Regulation, Advice and Information - The Government's Proposals (1999); Welfare Reform and Pensions Bill, HC Bill 44 (1998-9), clause 2.

113 See DSS, ibid, paras 10-11, where arguments for a single regulator are explicitly rejected.

114 See Treasury Select Committee, op cit n 102, para 53.

115 Taylor, in evidence to Treasury Select Committee, op cit $\mathrm{n}$ 57, para 184.

116 Taylor, memorandum of evidence to Treasury Select Committee, ibid, para 7.

117 The absence of such theorising in the approach to regulatory design is not unusual in the UK. It has been observed that "it is characteristic of our administrative law that machinery should evolve in piecemeal fashion and with no single set of clearly defined objectives. Utilities regulation has been peculiarly susceptible, given the scale and complexity of the privatisation process, as also a steep learning curve for government and agencies alike. Diversity in powers and performance is one trait which the regulation shares": Harlow and Rawlings, $o p$ cit $\mathrm{n} 105, \mathrm{p} 318$. 


\section{CONCLUSION}

The argument advanced in this article is that the social goal of pension provision - to ensure that as many as possible attain an adequate level of income on retirement - gives rise to distinctive challenges for regulation of the PP and creates a particular need for effective risk management to ensure that the objective is fulfilled. In spite of its initial assurances, there are reasons to question whether, especially in the long term, FSA regulation will prove to be sufficiently sensitive to these issues. Such anxiety points us toward the creation of a focused regulatory agency in which the skills necessary to manage this distinctive and complex product can be evolved and which avoids the hazards of an undifferentiated approach.

Of course, institutional reform will not in itself provide a panacea to the problems that have beset the personal pension market. It is important that the creation of an appropriate regulatory structure is combined with the promulgation of rules which properly address the potential abuses which may occur, coupled with a preparedness to enforce these rules rigorously, imposing sanctions where necessary. The Labour Government, mindful of the continued role for the PP in its welfare policy, ${ }^{118}$ has adopted a number of additional measures in an attempt to "put right the wrongs of pensions misselling". ${ }^{119}$ An equally robust approach will be required of the FSA, or any alternative regulator, if similar incidents are to be avoided in the future.

118 See DSS, op cit n 1, ch.3, para 9: “appropriately regulated, personal pensions will be the right option for some, mainly higher paid people". Note also the Government projection that the present 60:40 ratio of state to private provision will be reversed over the next fifty years: ibid, ch.12, para 4 .

119 See Liddell, 301 HC Deb 155-7 (18 November 1997). Note also various FSA advertising campaigns: see FSA Press Release 18/98 (14 April 1998), 001/99 (5 January 1999). 